\title{
'Chenguang', a new tetraploid Chinese jujube cultivar
}

Liu PING, Dai LI, Liu MenguUn*, Jiang Hong’en, Zhao ZHiHUI, Wang JiURUI

Res. Cent. Chinese Jujube, Agric. Univ. Hebei, Baoding, China 071001, lilyliu2005@yahoo.com.cn, Imj1234567@yahoo.com.cn, yylp@hebau.edu.cn, 1043072537@qq.com

${ }^{*}$ Correspondence and reprints

Fruits, 2012, vol. 67, p. 293-296 (C) 2012 Cirad/EDP Sciences All rights reserved DOI: 10.1051/fruits/2012019 www.fruits-journal.org

RESUMEN ESPAÑOL, p. 296

\section{'Chenguang', a new tetraploid Chinese jujube cultivar.}

Abstract - Introduction. Chinese jujube originated in China and has become a leading fruit tree in the northern part of China with total production of 4,250,000 $\mathrm{t}$ in 2009 and total planting area of 1,500,000 ha. Among the reported 944 Chinese jujube cultivars or strains, 'Zanhuangdazao' is the unique natural triploid cultivar; it is characterized by big fruit, high yield and good adaptability compared with the other diploid cultivars. Therefore, our group began polyploid breeding through colchicine induction starting in 2000. Cultivar origin. 'Chenguang' is a new Chinese jujube cultivar induced by colchicine on the stem apex of the diploid 'Linyilizao'. Through three years of top-grafting and purification, its characteristics were observed in grafted and top-grafted experimental orchards continually. In 2009, 'Chenguang' was released by the Hebei Forestry Cultivar Examination and Approval Committee and became the unique tetraploid Chinese jujube cultivar in the world to date. Cultivar characteristics. The somatic chromosome number, botanical character, phenological phase, productivity and adaptability are given. 'Chenguang' is suitable for growing in Shanxi, Hebei, Shandong Province, where the annual average temperature is $12-14^{\circ} \mathrm{C}$ and rainfall is above $400 \mathrm{~mm}$, or similar soil and climate conditions. Main cultural techniques. Propagation, the training system, fruit setting and disease control are explained and recommended.

China / Zizipbus jujuba / plant breeding / chromosome number / induced polyploidy / varieties / agronomic characters

\section{'Chenguang' , un nouveau cultivar tétraploïde de jujubier chinois.}

Résumé - Introduction. Le jujubier chinois est originaire de Chine ; il est devenu un arbre fruitier de premier plan dans le nord de la Chine avec une production totale de $4.250 .000 \mathrm{t}$ en 2009 pour une superficie totale de plantation de 1.500.000 ha. Parmi les 944 cultivars ou souches de jujubiers chinois signalés, "Zanhuangdazao " est l'unique cultivar triplö̈de naturel ; il est caractérisé par de gros fruits, un rendement élevé et une bonne adaptabilité comparé aux cultivars diploïdes. Notre groupe a donc entrepris la sélection de polyplö̈des de jujubier par induction à la colchicine à partir de l'an 2000. Origine du cultivar. "Chenguang " est un nouveau cultivar de jujubier chinois induit par colchicine sur apex de la tige du diploïde "Linyilizao ". Après trois ans de surgreffage et de purification, ses caractéristiques ont été observées en vergers expérimentaux continuellement greffés et surgreffés. En 2009, le cultivar "Chenguang " a été mis sur le marché par le comité de validation et de caractérisation des cultivars de sylviculture de Hebei et il est à ce jour l'unique cultivar tétraploïde de jujubier chinois de par le monde. Caractéristiques du cultivar. Le nombre de chromosomes somatiques, les caractères botaniques, la phase phénologique, la productivité, l'adaptabilité ont été étudiés. Le cultivar "Chenguang" est adapté à la culture dans le Shanxi, du Hebei, province de Shandong (Chine), où la température moyenne annuelle est de $12-14^{\circ} \mathrm{C}$ et les précipitations sont supérieures à $400 \mathrm{~mm}$, ou dans toutes autres régions présentant des conditions pédologiques et climatiques analogues. Principales techniques culturales. La propagation, la taille de formation, la mise à fruit, et le contrôle des maladies ont été décrits et des recommandations sont données.

Chine / Zizipbus jujuba / amélioration des plantes / nombre chromosomique / polyploïdie provoquée / variété / caractère agronomique 


\section{Introduction}

Chinese jujube originated in China. To date, more than forty countries including South Korea, the United States, Australia, Japan, Macedonia, Bulgaria, France, etc. have induced and utilized Chinese jujube as a potential fruit tree. Also, South Korea, the United States and Australia began breeding by selection from seedlings.

Chinese jujube has become a leading fruit tree in the northern part of China with total production of 4,250,000 $\mathrm{t}$ in 2009 [1] and planting area of 1,500,000 ha. Among the reported 944 Chinese jujube cultivars or strains, 'Zanhuangdazao' is the unique natural triploid cultivar; it is characterized by big fruit, high yield and good adaptability compared with the other diploid cultivars [2]. Therefore, our research group began polyploid breeding by using colchicines starting in 2000.

\section{Cultivar origin}

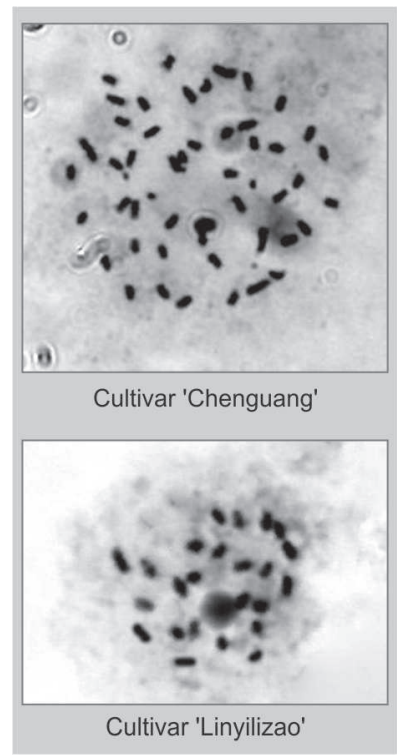

Figure 1.

Somatic chromosome numbers of the 'Chenguang' and 'Linyilizao' cultivars of jujube trees.
'Chenguang' is a new Chinese jujube cultivar induced by colchicine on the stem apex of the diploid 'Linyilizao' [3]. Through three years of top-grafting and purification, its characteristics were observed in grafted and top-grafted experimental orchards continually. Compared with 'Linyilizao', 'Chenguang' has a doubled chromosome number, shorter internodes, bigger but less lenticels, shorter bearing shoots, bigger, thicker and darker leaves, more chloroplast in bigger guard cells, four-aperture pollen, bigger fruits and better fruit quality. In 2009, 'Chenguang' was released by the Hebei Forestry Cultivar Examination and Approval Committee.

\section{Cultivar characteristics}

The somatic chromosome number of 'Chenguang' is $2 n=4 x=48$, which is doubled compared with that of 'Linyilizao' (figure 1).

The tree of 'Chenguang' has a less straight trunk and strong vigor, with a naturally round and open canopy. Young extension shoots are dark red with less and shorter thorns. The bearing shoots are $20.6 \mathrm{~cm}$ long with 12 leaves on average. Leaves are ovoid, thick, dark green, $5.5 \mathrm{~cm}$ long and $3.7 \mathrm{~cm}$ wide. It has a round leaf base, blunt leaf apex and saw tooth on the leaf margin. The flower normally opens from 14:00-16:00 daily. However, the opening time depends on the weather (light and temperature) just like the other Chinese jujube cultivars. The flower is $0.37 \mathrm{~cm}$ in diameter with lots of pollen. Two kinds of pollen were observed under a microscope. Pollen with four apertures accounted for $11.2 \%$ and the other pollen had three apertures. The pollen shows higher vitality of more than $70 \%$. The red fruits are round, $4.31 \mathrm{~cm}$ in vertical length and $4.21 \mathrm{~cm}$ in diameter, with average weight of $39.6 \mathrm{~g}$. The edible ratio is $98.5 \%$ and the pericarp is thin. The pulp is white and the fruits taste juicy, sweet and crispy. The hardness of the pulp is $9.6 \mathrm{~kg} \cdot \mathrm{cm}^{-2}$ and soluble sugar content can reach $22.3 \%$. The stone is inverted spindle-shaped with average weight of $0.60 \mathrm{~g}$. Like 'Linyilizao', embryos of 'Chenguang' are aborted at a very early stage and there is no kernel in the fruits.

In Xianxian County, Hebei, 'Chenguang' sprouts in mid-April, followed by shoot extension and flower bud differentiation. Normally, the flowers blossom from early June to the end of July. Fruits grow and become white in early September and mature in mid- to late September. The total growth of fruits lasts $100 \mathrm{~d}$. 'Chenguang' is a mid-ripening Chinese jujube table cultivar. Defoliation happens from October, followed by abscission of bearing shoots at the end of October. Thus, the total vegetative growth lasts approximately $190 \mathrm{~d}$.

Normally, 'Chenguang' gives fruits at an early age, i.e., 2-3 years old. Three years after top-grafting, trees could produce $5.6 \mathrm{~kg}$ fruits per year. Furthermore, the young extension shoots even set fruits under top removal treatment.

Similar to other Chinese jujube cultivars, 'Chenguang' shows good adaptability to drought, salinity and poor soil. It is suitable for growing in Shanxi, Hebei, Shandong Province, where the annual average temperature is $12-14{ }^{\circ} \mathrm{C}$ and rainfall is above 
$400 \mathrm{~mm}$. Fruit cracking, which is very serious on many leading cultivars, never occurs during the ripening time of 'Chenguang' even on rainy days. However, shrinking disease caused by single or mixed fungi, i.e., Alternaria alternata (Fr.) Keissler, Phoma destructiva Plowr., Fusicoccum sp., etc., is as serious as that in 'Linyilizao'.

\section{Main cultural techniques}

'Chenguang' is propagated by grafting on sour jujube (Ziziphus acidojujuba C. Y. Cheng et M.J. Liu) seedlings or top-grafting on other Chinese jujube trees. Cultivation spacing of 2-3 $\mathrm{m} \times 3-4 \mathrm{~m}$ and an open training system are strongly recommended. 'Chenguang' has characteristics of self-pollination; however, pollinating trees are helpful in fruit set.

Several key techniques can be conducted to improve the yield and fruit quality. Because shoot extension, flower bud differentiation, flower blooming and fruit setting are temporally overlapped, it is necessary to remove the top of extension shoots before and during the blooming period. Relative air humidity of more than $70 \%$ and temperature of $24-26{ }^{\circ} \mathrm{C}$ are acceptable during the blooming time. Therefore, water spraying or boron spraying is encouraged in early and mid-June. Also, at blooming time, girdling greatly increases fruit quantity.

In view of shrinking disease control, removal of diseased deciduous leaves, branches and fruits should be carried out in winter. Thereafter, it is profitable to spray fungicide 3-4 times from the end of June to the end of August at intervals of 10-15 d the next year. In addition, manure management and irrigation are essential to maintain tree vigor.

\section{Information}

This work was financed by the Agricultural Scientific Research Achievement Transformation Program (2010GB2A200027).

\section{References}

[1] Anon., China Agriculture Yearbook, China Agric. Publ. House, Beijing, China, 2010.

[2] Liu M.J., Wang M., Germplasm resources of Chinese jujube, China For. Publ. House, Beijing, China, 2009.

[3] Jiang H.E., Liu M.J., Studies on polyploid induction of Chinese jujube with colchicine, Acta Hortic. Sin. 31 (2004) 647-650. 


\section{'Chenguang', un nuevo cultivar tetraploide de azufaifo chino.}

Resumen - Introducción. El azufaifo chino es originario de China. Se ha convertido en un frutal de primer orden en el norte de China con una producción total de 4.250.000 t en 2009 para una superficie de plantación total de 1.500.000 ha. Entre los 944 cultivares o tocones de azufaifos chinos señalados, "Zanhuangdazao" es el único cultivar triploide natural. Se le caracteriza por sus grandes frutos, un elevado rendimiento y una buena adaptabilidad, en comparación con los cultivares diploidos. Nuestro grupo se dispuso por lo tanto a seleccionar poliploides de azufaifo por inducción con colchicina a partir de 2000. Origen del cultivar. " Chenguang " es un nuevo cultivar de azufaifo chino inducido por colchicina en la yema apical del diploido "Linyilizao ". Después de tres años de sobreinjerto y de purificación, se observaron sus características en vergeles experimentales continuamente injertados y sobreinjertados. En 2009, el cultivar "Chenguang" se lanzó al mercado por el comité de validación y de caracterización de los cultivares de silvicultura de Hebei y, a día de hoy, es el único cultivar tetraploide de azufaifo chino a través del mundo. Características del cultivar. Se estudiaron el número de cromosomas somáticos, los caracteres botánicos, la fase fenológica, la productividad y la adaptabilidad. El cultivar "Chenguang " está adaptado al cultivo en el Shanxi, Hebei, provincia de Shandong (China), donde la temperatura media anual es de $12-14{ }^{\circ} \mathrm{C}$ y las precipitaciones son superiores a $400 \mathrm{~mm}$, así como en cualquier otra región que presente semejantes condiciones edafológicas y climáticas. Principales métodos de cultivo. Se describieron la propagación, el tamaño de formación, la fructificación y el control de las enfermedades y se dieron igualmente recomendaciones.

China / Ziziphus jujuba / fitomejoramiento / número de cromosomas / poliploidia inducida / variedades / características agronómicas 